\title{
On the Role of Metal Contaminants in Catalyses with $\mathrm{FeCl}_{3}$
}

\author{
Stephen L. Buchwald ${ }^{*}$ [Prof. Dr.] \\ Massachusetts Institute of Technology Room 18-490 Cambridge, MA 02139 (USA) \\ Carsten Bolm ${ }^{*}$ [Prof. Dr.] \\ Institute for Organic Chemistry RWTH Aachen University Landoltweg 1, D-52056 Aachen \\ (Germany)
}

\section{Keywords}

Arylation; Catalysis; Copper; Iron trichloride; Metal Impurities

\begin{abstract}
Metal catalysis has a dominant role in modern organic chemistry. In particular, crosscoupling reactions allow bond formations, which have previously been impossible to perform. ${ }^{[1]}$ Precious metal catalysts dominate the field, but alternative systems based on nickel and copper salts have also, historically, been important. In particular, recent systems based on these metals have been described that provide products in a highly efficient manner. ${ }^{[2]}$
\end{abstract}

In this context, one of us (C.B.) reported iron-catalyzed cross-couplings leading to arylated amides, phenols, thiols and alkynes. ${ }^{[3,4]}$ Commonly, $10 \mathrm{~mol} \%$ of an iron salt in combination with $20 \mathrm{~mol} \%$ of a ligand (a diamine or a diketone) in a solvent such as toluene at $135{ }^{\circ} \mathrm{C}$ (using closed vials) was used. It was noticed by chemists at RWTH and MIT (past and present) that the catalyst activity depended on the metal salt purity and even more so on its commercial source. ${ }^{[5]}$ Also, a parallel between the results with the iron systems and some of those realized with copper catalysts by S.L.B.'s group and that of Song was recognized. For example, as in the case of much of the chemistry from S.L.B.'s group, N,N'-dimethyl-1,2diamines were superior ligands, and the best results were realized in conversions of aryl iodides.

These observations prompted us to collaborate to investigate whether it was possible that trace amounts of copper impurities were influencing these reactions. Thus, different sources of $\mathrm{FeCl}_{3}$ (from >98-99.99\% metal purity) were examined in the couplings of pyrazole, phenyl amide, phenol and thiophenol with aryl iodides. The literature data and the new results (obtained by B. Fors and R. Martin in the S.L.B. group) are shown below (Tables 14).

In all cases when $>99.99 \% \mathrm{FeCl}_{3}$ was employed lower yields were obtained than when the reactions were run using $>98 \% \mathrm{FeCl}_{3} \cdot{ }^{[6,7]}$ Furthermore, when different sources of $>98 \%$ $\mathrm{FeCl}_{3}$ were used different results were observed. These findings suggest that both the purity and the source of the $\mathrm{FeCl}_{3}$ play a crucial role in the success of these transformations.

In order to further investigate the cause of these findings, small amounts of $\mathrm{Cu}_{2} \mathrm{O}$ were added to the reactions using $>99.99 \% \mathrm{FeCl}_{3}$. With only $10 \mathrm{ppm}$ of $\mathrm{Cu}_{2} \mathrm{O}$ a significant increase in yield was observed in all cases. ${ }^{\left[{ }^{[, 9]}\right.}$ Moreover, in two cases examined, essentially

*FAX: (+1)-617-252-3297 sbuchwald@ MIT.EDU. *Fax: (+49)-241-8092-391 Carsten.Bolm@oc.rwth-aachen.de. 
identical results were obtained if the reaction was carried out in the absence of $\mathrm{FeCl}_{3}$, but in the presence of DMEDA and as little as $10 \mathrm{ppm}$ of $\mathrm{Cu}_{2} \mathrm{O}$ (Tables 1 and 2, last entries).

Although questions remain, we conclude that the outcome of the reported reactions with $\mathrm{FeCl}_{3}$ may in certain cases be significantly affected by trace quantities of other metals, particularly copper. Considering that metal contaminants have also been found relevant in other processes involving metals (such as the chromium-mediated Nozaki-Hiyama-Kishi reaction, ${ }^{[10]}$ olefinations and Simmons-Smith reactions with organozinc reagents, ${ }^{[11]}$ and "metal-free" Suzuki-[12] and Sonogashira-coupling ${ }^{[13]}$, we suspect that the presence of trace metal impurities may play a more important role than is generally assumed.

\section{Acknowledgments}

C.B. is grateful to the Fonds der Chemischen Industrie for the financial support and thanks Prof. Dr. R. Dronskowski and Mr. L. Stork (Institute for Inorganic Chemistry, RWTH Aachen University) for substrate analyses by Atom Absorption Spectroscopy. S.L.B. acknowledges the National Institutes of Health (GM46059 and 58160 ). We also thank Dr. A. Klapars and Professor Dr. J. Antilla for insightful comments. Further, we are indebted to Mr. B. Fors and Dr. R. Martin for experimental results and Prof. Dr. A. Fürstner (MPI, Mülheim, Germany) and Prof. Dr. M. Beller (LIKAT, Rostock, Germany) for performing control experiments.

\section{References}

[1]. a) de Meijere, A.; Diederich, F., editors. Metal-catalyzed Cross-Coupling Reactions. 2nd ed.. Wiley-VCH; Weinheim: 2004. b) Corbet J-P, Mignani G. Chem. Rev. 2006; 106:2651. [PubMed: 16836296] c) Buchwald SL. Acc. Chem. Res. 2008; 41:1439. [PubMed: 19032082] d) Surry DS, Buchwald SL. Angew. Chem. 2008; 120:6438.Angew. Chem. Int. Ed. 2008; 47:6338.

[2]. Reviews: Ley SV, Thomas AW. Angew. Chem. 2003; 115:5558.; Angew. Chem., Int. Ed. 2003; 42:5400.; Kunz K, Scholz U, Ganzer D. Synlett. 2003:2428.; Beletskaya IP, Cheprakov AV. Coord. Chem. Rev. 2004; 248:2337.; Corbert J-P, Mignani G. Chem. Rev. 2006; 106:2651. [PubMed: 16836296] ; Carril M, SanMartin R, Domínguez E. Chem. Soc. Rev. 2008; 37:639. [PubMed: 18362973] ; Monnier F, Taillefer M. Angew. Chem. 2008; 120:3140.; Angew. Chem., Int. Ed. 2008; 47:3096.; Ma D, Cai Q. Acc. Chem. Res. 2008; 41:1450. [PubMed: 18698852] ; Evano G, Blanchard N, Toumi M. Chem. Rev. 2008; 180:3054. [PubMed: 18698737] .

[3]. a) Correa A, Bolm C. Angew. Chem. 2007; 119:9018.Angew. Chem. Int. Ed. 2007; 46:8862.b) Correa A, Bolm C. Adv. Synth. Catal. 2008; 350:391.c) Correa A, Elmore S, Bolm C. Chem. Eur. J. 2008; 14:3527. [PubMed: 18338368] d) Bistri O, Correa A, Bolm C. Angew. Chem. 2008; 120:596.Angew. Chem. Int. Ed. 2008; 47:586.e) Bonnamour J, Bolm C. Org. Lett. 2008; 10:2665. [PubMed: 18507387] f) Correa A, Carril M, Bolm C. Angew. Chem. 2008; 120:2922.Angew. Chem. Int. Ed. 2008; 47:2880.g) Carril M, Correa A, Bolm C. Angew. Chem. 2008; 120:4940.Angew. Chem. Int. Ed. 2008; 47:4862.h) Correa A, Carril M, Bolm C. Chem. Eur. J. 2008; 14:10919. [PubMed: 19016561]

[4]. Recently, it was reported that $\mathrm{N}$-arylations in water with $\mathrm{FeCl}_{3}$ under otherwise identical conditions as applied in ref. 3 a gave essentially the same results. Teo Y-C. Adv. Synth. Catal. 2009; 351:720.

[5]. The best results were achieved with $\mathrm{FeCl}_{3}$ having a purity of $>98 \%$ (from Merck). According to Atom Absorption Spectroscopy the major contaminant in this sample is manganese (ca. $0.17 \%$ ). Control experiments showed this to be catalytically inactive. A. Correa, M. Carril, C. Bolm, to be published. The copper content was determined to be $0.034 \%$.

[6]. This is consistent with observations reported for the $\mathrm{N}$-arylations of sulfoximines (ref. $3 \mathrm{~b}$ ).

[7]. Also in iron-catalyzed alkylations of aromatic Grignard reagents the purity of the $\mathrm{FeCl}_{3}$ is important. See: Cahiez G, Habiak V, Duplais C, Moyeux A. Angew. Chem. 2007; 119:4442.; Angew. Chem. Int. Ed. 2007; 46:4364..

[8]. Professor Dr. Per-Ola Norrby (University of Gothenburg, Sweden) kindly informed us about analogous observations found independently. For a summary of those findings, see: Larsson P-F, Correa A, Carril M, Norrby P-O, Bolm C. Angew. Chem. accepted for publication (anie 200902236). 
[9]. For Fe/Cu co-catalyses (with commonly catalyst loadings in the $10 \mathrm{~mol} \%$ range for both metals), see Taillefer M, Xia N, Oualli A. Angew. Chem. 2007; 119:952.; Angew. Chem. Int. Ed. 2007; 46:934.; Song R-J, Deng C-L, Xie Y-X, Li J-H. Tetrahedron Lett. 2007; 48:7845.; Wang Z, Fu H, Jiang Y, Zhao Y. Synlett. 2008:2540.; Rao Volla CM, Vogel P. Tetrahedron Lett. 2008; 49:5961.; Mao J, Xie G, Wu M, Guo J, Ji S. Adv. Synth. Catal. 2008; 350:2477.; Huang H, Jiang H, Chen K, Liu H. J. Org. Chem. 2008; 73:9061. [PubMed: 18937417] ; Ku X, Huang H, Jiang H, Liu H. J. Comb. Chem. 2009; 11:338. [PubMed: 19260652] ; Li S, Jia W, Jiao N. Adv. Synth. Catal. 2009; 351:569..

[10]. a) Takai K, Tagashira M, Kuroda T, Oshima K, Utimoto K, Nozaki H. J. Am. Chem. Soc. 1986; 108:6048. [PubMed: 22175376] b) Jin H, Uenishi J, Christ WJ, Kishi Y. J. Am. Chem. Soc. 1986; 108:5644.

[11]. a) Takai K, Kakiuchi T, Kataoka Y, Utimoto K. J. Org. Chem. 1994; 59:2668.b) Takai K, Kakiuchi T, Utimoto K. J. Org. Chem. 1994; 59:2671.

[12]. a) Arvela RK, Leadbeater NE, Sangi MS, Williams VA, Granados P, Singer RD. J. Org. Chem. 2005; 70:161. [PubMed: 15624918] b) Alimardanov A, Schmieder-van de Vondervoort L, de Vries AHM, de Vries JG. Adv. Synth. Catal. 2004; 346:1812.

[13]. For an excellent highlight providing additional insight into the importance of trace metals in palladium-catalyzed Sonogashira reactions, see: Plenio H. Angew. Chem. 2008; 120:7060.; Angew. Chem. Int. Ed. 2008; 47:6954.. 
Table 1

$\mathrm{N}$-Arylation in the presence of $\mathrm{FeCI}_{3}$ (pyrrazole).

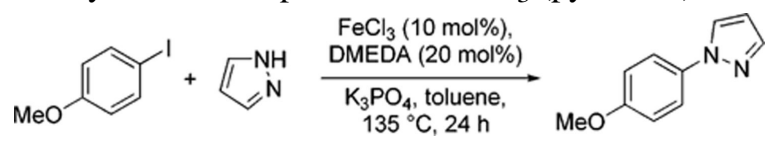

\begin{tabular}{|c|c|}
\hline $\mathrm{FeCI}_{3}$ & 3C Yield (\%) \\
\hline$>98 \%$ (Merck) & 87 (ref. 3a) \\
\hline$>98 \%$ (Aldrich) & 26 \\
\hline$>99.99$ (Aldrich) & 9 \\
\hline$>99.99 \%+5 \mathrm{ppm} \mathrm{Cu}_{2} \mathrm{O}$ & 78 \\
\hline$>99.99 \%+10 \mathrm{ppm} \mathrm{Cu}_{2} \mathrm{O}$ & 79 \\
\hline no $\mathrm{Fe}+$ ligand $+5 \mathrm{ppm} \mathrm{Cu}_{2} \mathrm{O}$ & 77 \\
\hline no $\mathrm{Fe}+$ no ligand $+5 \mathrm{ppm} \mathrm{Cu}_{2} \mathrm{O}$ & 23 \\
\hline
\end{tabular}




\section{Table 2}

$\mathrm{N}$-Arylation in the presence of $\mathrm{FeCI}_{3}$ (phenyl amide).

\begin{tabular}{|c|c|}
\hline \multirow{2}{*}{\multicolumn{2}{|c|}{ 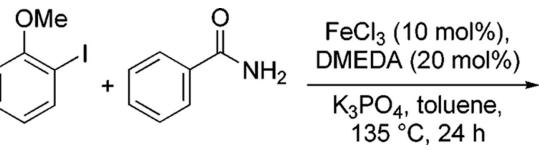 }} \\
\hline & \\
\hline $\mathrm{FeCI}_{3}$ & GC Yield (\%) \\
\hline$>98 \%$ (Merck) & 79(ref. 3c) \\
\hline$>98 \%$ (Aldrich) & 16 \\
\hline$>99.99$ (Aldrich) & trace \\
\hline$>99.99 \%+5 \mathrm{ppm} \mathrm{Cu}_{2} \mathrm{O}$ & 98 \\
\hline 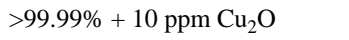 & 99 \\
\hline no $\mathrm{Fe}+$ ligand $+5 \mathrm{ppm} \mathrm{Cu}_{2} \mathrm{O}$ & 97 \\
\hline no $\mathrm{Fe}+$ no ligand $+5 \mathrm{ppm} \mathrm{Cu}_{2} \mathrm{O}$ & 34 \\
\hline
\end{tabular}


Table 3

O-Arylation in the presence of $\mathrm{FeCI}_{3}$.

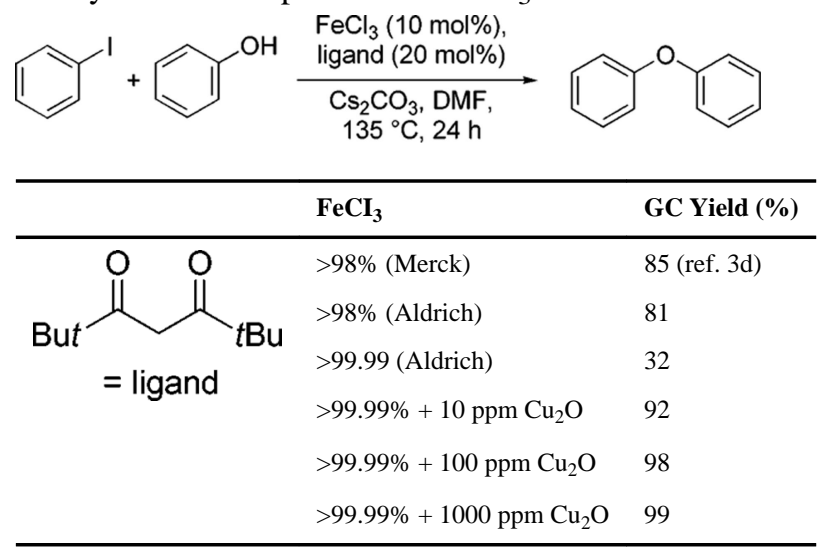


Table 4

$\mathrm{S}$-Arylation in the presence of $\mathrm{FeCI}_{3}$.

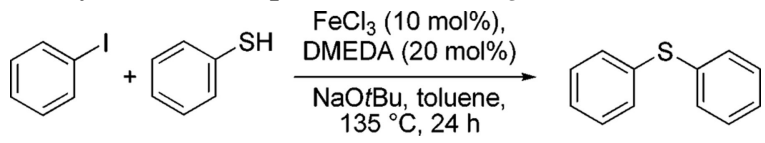

\begin{tabular}{lr}
\hline $\mathbf{F e C I}_{\mathbf{3}}$ & GC Yield (\%) \\
\hline$>98 \%$ (Merck) & 91 (ref. $3 \mathrm{f}$ ) \\
$>98 \%$ (Aldrich) & 4 \\
$>99.99$ (Aldrich) & 2 \\
$>99.99 \%+10 \mathrm{ppmCu}_{2} \mathrm{O}$ & 42 \\
$>99.99 \%+100 \mathrm{ppm} \mathrm{Cu}_{2} \mathrm{O}$ & 99 \\
$>99.99 \%+1000 \mathrm{ppm} \mathrm{Cu}_{2} \mathrm{O}$ & 93 \\
\hline
\end{tabular}

